From Ritual to Romance 
Other works by Jessie Laidlay Weston (1850-1928):

Legends of the Wagner Drama (1896)

The Legend of Sir Gawain (1897)

King Arthur and His Knights (1899)

The Romance of Charlemagne and His Peers (1900)

The Legend of Sir Lancelot du Lac (1901)

The Three Days' Tournament (1902)

Sir Gawain and the Green Knight (1905)

Sir Gawain and the Lady of Lys (1907)

The Legend of Sir Percival vol. i (1906), vol. ii (1909)

A Hitherto Unconsidered Aspect of the Round Table (1910)

Romance, Vision and Satire English Alliterative

Poems of the 14th century (1912)

The Quest of the Holy Grail (1913)

(Editor) The Chief Middle English Poets (1914)

Germany's Literary Debt to France (1915)

From Ritual to Romance (1920) (Awarded the

Crawshay Prize for 1920) 


\section{JESSIE L. WESTON}

\section{From Ritual to Romance}

PRINCETON UNIVERSITY PRESS

PRINCETON, NEW JERSEY 
Published by Princeton University Press, 41. William Street,

Princeton, New Jersey 08540

In the United Kingdom: Princeton University Press,

Chichester, West Sussex

Foreword to the 1993 edition copyright (C) 1993

Princeton University Press

Translations of verse and prose excerpts copyright (C) 1957

Mary McLaughlin

All Rights Reserved

Weston, Jessie Laidlay, $1850-19^{28}$.

From ritual to romance / Jessie L. Weston.

p. cm.-(Mythos)

Originally published: 1920 . With a new foreword

by Robert A. Segal.

Includes bibliographical references and index.

ISBN o-691-02 107-4 (pbk.)

1. Grail-Romances-History and criticism.

2. Romances-History and criticism.

I. Title. II. Series: Mythos (Princeton, N.J.)

PN686.G7 451993

$8 \mathrm{Og}^{\prime} \cdot 915$ - dc2o $\quad 92-37533$

First Princeton Paperback printing, for the Mythos Series, 1993, with the permission of Cambridge University Press

Princeton University Press books are printed on acid-free paper and meet the guidelines for permanence and durability of the Committee on Production Guidelines for Book Longevity of the

Council on Library Resources

$$
\begin{array}{llllll}
5 & 7 & 9 & 10 & 8 & 6
\end{array}
$$

Printed in the United States of America

http://pup.princeton.edu 
"Animus ad amplitudinem Mysteriorum pro modulo suo dilatetur, non Mysteria ad angustias animi constringantur." Bacon

"Many literary critics seem to think that an hypothesis about obscure and remote questions of history can be refuted by a simple demand for the production of more evidence than in fact exists.-But the true test of an hypothesis, if it cannot be shewn to conflict with known truths, is the number of facts that it correlates, and explains." (Cornford, Origins of Attic Comedy) 
